\title{
The changes in preferences for venous thromboembolism prophylaxis after total joint arthroplasty in Turkey: A survey
}

\author{
Türkiye'de total eklem artroplastisi sonrası venöz tromboembolizm \\ profilaksisi tercihlerindeki değişimler: Bir anket
}

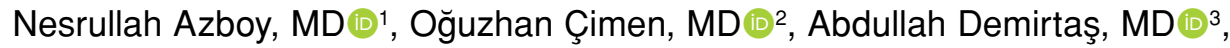 \\ Serhat Elçi, MD $\mathbb{B}^{4}$, İbrahim Azboy, MD (iD ${ }^{5}$ \\ 'Department of Public Health, Mustafa Kemal University Faculty of Medicine, Hatay, Turkey \\ ${ }^{2}$ Department of Orthopedics and Traumatology, İstanbul Medipol Hospital, İstanbul, Turkey \\ ${ }^{3}$ Department of Orthopedics and Traumatology, Medeniyet University Faculty of Medicine, İstanbul, Turkey \\ ${ }^{4}$ Department of Orthopedics and Traumatology, Dicle University Faculty of Medicine, Diyarbakır, Turkey \\ ${ }^{5}$ Department of Orthopedics and Traumatology, Medipol University Faculty of Medicine, İstanbul, Turkey
}

\begin{abstract}
Objectives: This study aims to investigate the changes in preferences of orthopedic surgeons for venous thromboembolism (VTE) prophylaxis after total knee arthroplasty (TKA) and total hip arthroplasty (THA) and the factors that affect such changes in Turkey.
\end{abstract}

Materials and methods: Turkish Orthopedics and Traumatology Association members $(n=2,180)$ were invited to fill in the questionnaire. A total of 366 orthopedic surgeons responded and completed questionnaire. The questionnaire was comprised of 12 questions investigating the demographics of surgeons, their preferences for VTE prophylaxis, the changes in their preferences over the course of the past three years, and the causes of such changes.

Results: In the past three years, $31.1 \%$ of surgeons changed their VTE prophylaxis method and $32.7 \%$ used risk classifications. The use of low molecular weight heparin (LMWH) decreased from $89.4 \%$ to $42.5 \%$ and from $85.8 \%$ to $44.2 \%$ after TKA and THA, respectively. The use of aspirin increased from $10.6 \%$ to $43.4 \%$ and from $9.7 \%$ to $37.2 \%$ after TKA and THA, respectively. The use of oral anticoagulants increased from $11.5 \%$ to $41.6 \%$ and from $10.6 \%$ to $39.8 \%$ after TKA and THA, respectively. Still, orthopedic surgeons in Turkey preferred LMWH at rates of $75.7 \%$ and $74 \%$ after TKA and THA, respectively. Congressional presentations were the first $(47.7 \%)$ among the causes of the changes in preferences for VTE prophylaxis. Preferences of up to $60 \%$ of surgeons working at universities were influenced by the American Academy of Orthopedic Surgeons guidelines.

Conclusion: In the past three years, approximately one third of orthopedic surgeons changed their preferences for VTE prophylaxis after total joint arthroplasty in Turkey. Changes in preferences were largely in favor of aspirin and oral anticoagulants in parallel to changes in guidelines for VTE prevention.

Keywords: Arthroplasty; prophylaxis; questionnaire; Turkey; venous thromboembolism.

\section{ÖZ}

Amaç: Bu çalışmada Türkiye'de total diz artroplastisi (TDA) ve total kalça artroplastisi (TKA) sonrası ortopedik cerrahların venöz tromboembolizm (VTE) profilaksisi tercihlerindeki değişimler ve bu değişimlerde etkili olan faktörler araştırıldı.

Gereç ve yöntemler: Türk Ortopedi ve Travmatoloji Derneği üyeleri $(n=2180)$ soru formunu doldurmaya davet edildi. Toplam 366 ortopedik cerrah yanıt verdi ve anketi tamamladı. Anket; cerrahların demografik özelliklerini, VTE profilaksisi tercihlerini, son üç yıl içerisinde tercihlerindeki değişimleri ve bu değişimlerin nedenlerini araştıran 12 sorudan oluşuyordu.

Bulgular: Son üç yıl içerisinde cerrahların \%31.1'i VTE profilaksisi yöntemini değiştirdi ve \%32.7'si risk sınıflaması kullandı. Düşük moleküler ağırlıklı heparin (DMAH) kullanımı TDA ve TKA sonrası sırasıyla $\% 89.4$ 'ten \%42.5'e ve \%85.8'den \%44.2'ye düstü. Aspirin kullanımı TDA ve TKA sonrası sirasiyla \%10.6'dan \%43.4'e ve \%9.7'den \%37.2'ye yükseldi. Oral antikoagülan kullanımı TDA ve TKA sonrası sırasıyla $\% 11.5$ 'ten \%41.6'ya ve \%10.6'dan \%39.8'e yükseldi. Bununla birlikte, Türkiye'de ortopedik cerrahlar TDA ve TKA sonrası sırasılla \%75.7 ve \%74 oranlarında DMAH tercih etti. Venöz tromboembolizm profilaksisi için tercihlerdeki değişimlerin nedenleri arasında kongre sunumları ilk sırada (\%47.7) idi. Üniversitelerde çalışan cerrahların \%60'a kadarının tercihleri Amerikan Ortopedik Cerrahlar Akademisi kılavuzlarından etkilendi.

Sonuç: Son üç yılda Türkiye'de ortopedik cerrahların yaklaşık üçte biri total eklem artroplastisi sonrası VTE profilaksisindeki tercihlerini değiştirdi. Venöz tromboembolizmin önlenmesi için kılavuzlardaki değişikliklere paralel olarak tercihlerdeki değişiklikler büyük oranda aspirinin ve oral antikoagülanların lehine idi.

Anahtar sözcükler: Artroplasti; profilaksi; anket; Türkiye; venöz tromboembolizm.

Received: May 29, 2018 Accepted: September 25, 2018

Correspondence: Nesrullah Azboy, MD. Mustafa Kemal Üniversitesi Tıp Fakültesi Halk Sağlığı Anabilim Dalı, 31060 Alahan, Hatay, Turkey

Tel: +90 506 - 8436155 e-mail: nesrullahazboy@gmail.com 
Total knee arthroplasty (TKA) and total hip arthroplasty (THA) are the most commonly performed operations in orthopedic surgery. Patient satisfaction and survival rates after total joint arthroplasty (TJA) are satisfactory. ${ }^{[1]}$ The number of TJAs are increasing. Venous thromboembolism (VTE) remains as a serious complication following TJA.[2] The number of VTEs are also increasing in correlation with the number of operations. This is reflected as increased cost in the country's economy. ${ }^{[3]}$

The optimal method for VTE prophylaxis after TJA remains controversial. In parallel with new surgical techniques, pain management protocols, neuroaxial anesthesia methods, early mobilization, and individualized VTE prophylaxis gained popularity to provide both effective VTE prophylaxis and prevent major and minor bleeding complications. ${ }^{[4-6]}$

Guidelines recommending mechanical and pharmacological methods for VTE prophylaxis are regularly renewed. These include the American College of Chest Physicians (ACCP), ${ }^{[7]}$ the American Academy of Orthopedic Surgeons (AAOS), ${ }^{[8]}$ and the National Institute for Health and Care Excellence. ${ }^{[9]}$ In parallel to new scientific developments, these guidelines sometimes change their recommendations. However, the alignment of orthopedic surgeons with the guidelines may differ due to their experiences and the facilities of the hospitals they work. This issue has been investigated in several studies. ${ }^{[9,10]}$ Therefore,

TABLE

Survey questions

1. Specify the institution you are working in.

2. Please indicate your academic position.

3. How many years have you been a specialist?

4. How many primary arthroplasty cases do you perform per month?

5. How many arthroplasty revisions cases do you perform per month?

6. What are your preferred venous thromboembolism prophylaxis options for knee arthroplasty?

7. What are your preferred thromboembolic prophylaxis options for hip arthroplasty?

8. Do you use risk classification to assess the risk of developing venous thromboembolism after arthroplasty?

9. Did you change your venous thromboembolism prophylaxis method after arthroplasty in the past three years?

10. What we your previous venous thromboembolism prophylaxis options for knee arthroplasty?

11. What we your previous venous thromboembolism prophylaxis options for hip arthroplasty?

12. What we effective in changing your preference for venous thromboembolism prophylaxis? in this study, we aimed to investigate the changes in preferences of orthopedic surgeons for VTE prophylaxis after TKA and THA and the factors that affect such changes in Turkey.

\section{MATERIALS AND METHODS}

This study was conducted between April 2017 and June 2017. Data of the study were obtained through an online survey from 366 orthopedic surgeons registered in Turkish Orthopedics and Traumatology Association database $(n=2,180)$ in 2016 and currently performing knee and hip arthroplasty. For this purpose, a draft questionnaire was prepared containing questions about the preferred VTE prophylaxis methods after TKA and THA and changes in preferences in the past three years. Five experienced surgeons operating more than 100 arthroplasties per year were consulted to evaluate the questionnaire. The questionnaire was finalized according to

TABLE II

Demographic data

\begin{tabular}{|c|c|c|}
\hline & $\mathrm{n}$ & $\%$ \\
\hline \multicolumn{3}{|l|}{ Workplace } \\
\hline District State Hospital & 46 & 12.6 \\
\hline Provincial State Hospital & 54 & 14.8 \\
\hline Research and Training Hospital & 84 & 23.1 \\
\hline Private Hospital & 87 & 23.9 \\
\hline University Hospital & 93 & 25.5 \\
\hline \multicolumn{3}{|l|}{ Academic position } \\
\hline Operator & 238 & 65.6 \\
\hline Assistant professor & 39 & 10.7 \\
\hline Associate professor & 48 & 13.2 \\
\hline Professor & 38 & 10.5 \\
\hline \multicolumn{3}{|l|}{ Expertise time (years) } \\
\hline $0-5$ & 128 & 35.1 \\
\hline $5-10$ & 80 & 21.9 \\
\hline $10-15$ & 48 & 13.2 \\
\hline $15-20$ & 46 & 12.6 \\
\hline $20-30$ & 45 & 12.3 \\
\hline$>30$ & 18 & 4.9 \\
\hline \multicolumn{3}{|c|}{ Number of primary arthroplasty per month } \\
\hline $1-5$ & 144 & 39.6 \\
\hline $5-10$ & 97 & 26.6 \\
\hline $10-20$ & 62 & 17 \\
\hline $20-30$ & 36 & 9.9 \\
\hline$>30$ & 25 & 6.9 \\
\hline \multicolumn{3}{|c|}{ Number of revision arthroplasty per month } \\
\hline Do not revise & 118 & 32.7 \\
\hline $1-5$ & 218 & 60.4 \\
\hline $5-10$ & 19 & 5.3 \\
\hline $10-20$ & 5 & 1.4 \\
\hline$>20$ & 1 & 0.3 \\
\hline
\end{tabular}


their suggestions. The questionnaire consisted of 12 questions investigating the demographics of surgeons, preferences for VTE prophylaxis, and factors influencing changes in prophylaxis preferences over the past three years (Table I).

\section{Statistical analysis}

All data were recorded in the IBM SPSS version 22.0 software (IBM Corp., Armonk, NY, USA). Descriptive statistics and chi-square test were used in the analysis of the data. Values of $\mathrm{p}<0.05$ were considered statistically significant.

\section{RESULTS}

Of the 366 surgeons participating in the survey, $46(12.6 \%)$ were working in district state hospitals, $54(14.8 \%)$ in provincial state hospitals, 84 (23.1\%) in education and research hospitals, $87(23.9 \%)$ in private hospitals and 93 (25.5\%) in university hospitals. Regarding academic positions, $238(65.6 \%)$ operators, $39(10.7 \%)$ assistant professors, $48(13.2 \%)$ associate professors, and $38(10.5 \%)$ professors participated in the survey (Table II).

An investigation of the surgeons' preferences for VTE prophylaxis revealed that low molecular weight heparin (LMWH) was the most commonly used method after TKA $(75.7 \%)$ and THA (74\%) (Table III). Of the 366 surgeons participating in the survey, 113 (31.1\%) changed their VTE prophylaxis preferences. Surgeons working in the provincial government hospitals preferred to change their VTE prophylaxis method the least $(22.2 \%)$ while surgeons working in private hospitals changed the most $(40.2 \%)$. However, there was no significant difference between surgeons in terms of the hospitals they worked $(p>0.05)$ (Table III). Associate professors changed their VTE prophylaxis method the most (40.4\%) while operators changed the least $(28.3 \%)$. However, there was no significant difference between academic positions in terms of VTE prophylaxis change ( $>>0.05$ ) (Table IV).

Among the 113 surgeons who changed their VTE prophylaxis, the most preferred agents were aspirin and oral anticoagulants (Table V). In the past three years, aspirin usage increased from $10.6 \%$ to $43.4 \%$ and from $9.7 \%$ to $37.2 \%$ after TKA and THA, respectively. In the same period, the use of oral anticoagulants increased from $11.5 \%$ to $41.6 \%$ and from $10.6 \%$ to $39.8 \%$ after TKA and THA, respectively. Aspirin was preferred most by professors $(54.2 \%)$ and least by operators $(32 \%)$. Oral anticoagulants were preferred most by assistant professors $(42.8 \%)$ and least by professors $(25 \%)$.

Factors influencing VTE prophylaxis changes were congressional presentations $(46 \%)$, followed by problems encountered by patients when using drugs (40\%) and colleagues' practices (39\%) (Table VI).

Regarding academic positions, professors mostly considered AAOS guidelines (58.3\%), while associate professors considered research studies (73.7\%) to change their VTE prophylaxis method after TJA (Table VII).

According to the institutions of surgeons who changed their VTE prophylaxis, $60 \%$ of surgeons

TABLO III

Venous thromboembolism prophylaxis preferences

\begin{tabular}{|c|c|c|c|c|}
\hline \multirow[b]{2}{*}{ Preference } & \multicolumn{2}{|c|}{ Knee } & \multicolumn{2}{|c|}{ Hip } \\
\hline & $\mathrm{n}$ & $\%$ & $\mathrm{n}$ & $\%$ \\
\hline Warfarin & 1 & 0.3 & 0 & 0 \\
\hline LMWH 15 days & 156 & 42.6 & 89 & 24.3 \\
\hline LMWH 30 days & 127 & 34.7 & 185 & 50.5 \\
\hline Oral anticoagulant agent 15 days & 25 & 6.8 & 5 & 1.4 \\
\hline Oral anticoagulant agent 30 days & 35 & 9.6 & 55 & 15 \\
\hline Mechanical leg pump & 29 & 7.9 & 28 & 7.7 \\
\hline Aspirin 100 mg 2x1 (2 weeks) & 11 & 3 & 9 & 2.5 \\
\hline Aspirin 100 mg 2x1 (6 weeks) & 35 & 9.6 & 30 & 8.2 \\
\hline Aspirin 300 mg 2x1 (2 weeks) & 4 & 1.1 & 3 & 0.8 \\
\hline Aspirin 300 mg 2x1 (6 weeks) & 6 & 1.6 & 9 & 2.5 \\
\hline LMWH + aspirin & 51 & 13.9 & 46 & 12.6 \\
\hline Only mechanic prophylaxis & 4 & 1.1 & 3 & 0.8 \\
\hline Vena cava filter & 3 & 0.8 & 4 & 1.1 \\
\hline Others & 20 & 5.5 & 21 & 5.7 \\
\hline
\end{tabular}

LMWH: Low molecular weight heparin. 
TABLE IV

Comparison of changes in venous thromboembolism prophylaxis and use of risk classification in terms of institutions and academic positions

\begin{tabular}{|c|c|c|c|c|c|c|c|c|c|c|}
\hline & \multicolumn{4}{|c|}{ VTE prophylaxis change } & \multirow[b]{3}{*}{$p$} & \multicolumn{4}{|c|}{ Risk classification usage } & \multirow[b]{3}{*}{$p$} \\
\hline & \multicolumn{2}{|c|}{ Yes } & \multicolumn{2}{|c|}{ No } & & \multicolumn{2}{|c|}{ Yes } & \multicolumn{2}{|c|}{ No } & \\
\hline & $\mathrm{n}$ & $\%$ & $\mathrm{n}$ & $\%$ & & $\mathrm{n}$ & $\%$ & $\mathrm{n}$ & $\%$ & \\
\hline \multicolumn{11}{|l|}{ Workplace } \\
\hline District State Hospital & 12 & 26.7 & 33 & 73.3 & \multirow{5}{*}{0.17} & 7 & 16.3 & 36 & 83.7 & \multirow{5}{*}{0.01} \\
\hline Provincial State Hospital & 12 & 22.2 & 42 & 77.8 & & 16 & 29.6 & 38 & 70.4 & \\
\hline Education and Research Hospital & 23 & 27.7 & 60 & 72.3 & & 30 & 36.1 & 53 & 73.9 & \\
\hline Private Hospital & 35 & 40.2 & 52 & 59.8 & & 28 & 32.2 & 59 & 67.8 & \\
\hline University Hospital & 30 & 32.6 & 62 & 76.4 & & 37 & 40.2 & 55 & 59.8 & \\
\hline \multicolumn{11}{|l|}{ Academic Positions } \\
\hline Operator & 67 & 28.3 & 170 & 71.7 & \multirow{4}{*}{0.35} & 54 & 23.0 & 181 & 77.0 & \multirow{4}{*}{0.00} \\
\hline Assistant professor & 14 & 35.9 & 25 & 74.1 & & 13 & 33.3 & 26 & 66.7 & \\
\hline Associate professor & 19 & 40.4 & 28 & 59.6 & & 28 & 59.6 & 19 & 40.4 & \\
\hline Professor & 12 & 32.4 & 25 & 67.6 & & 23 & 62.2 & 14 & 37.8 & \\
\hline
\end{tabular}

VTE: Venous thromboembolism.

working at universities changed their VTE prophylaxis due to the AAOS guidelines, while surgeons working at education and research hospitals preferred congressional presentations and colleagues' experiences equally (52.2\%). On the other hand, $48.6 \%$ of surgeons working at private hospitals changed their VTE prophylaxis due to congress presentations, while surgeons working at provincial state hospitals preferred congressional presentations and problems encountered by patients when using drugs (58.3\%) equally. In addition, $66.7 \%$ of surgeons working at county state hospitals changed their prophylaxis

TABLE V

Previously and currently preferred venous thromboembolism prophylaxis methods of 113 orthopedic surgeons who changed their prophylaxis preferences over past three years

\begin{tabular}{|c|c|c|c|c|c|c|c|c|}
\hline \multirow[b]{3}{*}{ Prophylaxis preference } & \multicolumn{4}{|c|}{ Total knee arthroplasty } & \multicolumn{4}{|c|}{ Total hip arthroplasty } \\
\hline & \multicolumn{2}{|c|}{ Current } & \multicolumn{2}{|c|}{ Previous } & \multicolumn{2}{|c|}{ Current } & \multicolumn{2}{|c|}{ Previous } \\
\hline & $\mathrm{n}$ & $\%$ & $\mathrm{n}$ & $\%$ & $\mathrm{n}$ & $\%$ & $\mathrm{n}$ & $\%$ \\
\hline Warfarin & 0 & & 2 & 1.8 & 0 & & 2 & 1.8 \\
\hline LMWH 15 days & 31 & 27.4 & 56 & 49.6 & 13 & 11.5 & 37 & 32.7 \\
\hline LMWH 30 days & 21 & 18.6 & 46 & 40.7 & 38 & 33.6 & 62 & 54.9 \\
\hline Oral anticoagulant agent 15 days & 16 & 14.2 & 10 & 8.8 & 5 & 4.4 & 4 & 3.5 \\
\hline Oral anticoagulant agent 30 days & 31 & 27.4 & 4 & 3.5 & 40 & 35.4 & 9 & 8 \\
\hline Mechanical leg pump & 8 & 7.1 & 6 & 5.3 & 10 & 8.8 & 6 & 5.3 \\
\hline Aspirin 100 mg $2 \times 1$ (2 weeks) & 5 & 4.4 & 6 & 5.3 & 4 & 3.5 & 2 & 1.8 \\
\hline Aspirin 100 mg $2 \times 1$ (6 weeks) & 18 & 15.9 & 2 & 1.8 & 14 & 12.4 & 2 & 1.8 \\
\hline Aspirin 300 mg $2 \times 1$ ( 2 weeks) & 3 & 2.7 & 0 & 0 & 3 & 2.7 & 0 & 0 \\
\hline Aspirin 300 mg $2 \times 1$ ( 6 weeks) & 3 & 2.7 & 0 & 0 & 5 & 4.4 & 1 & 0.9 \\
\hline Heparin + aspirin & 28 & 24.8 & 6 & 5.3 & 22 & 19.5 & 8 & 7.1 \\
\hline Only mechanics & 0 & 0 & 1 & 0.9 & 0 & 0 & 1 & 0.9 \\
\hline Vena cava filter & 1 & 0.9 & 1 & 0.9 & 1 & 0.9 & 1 & 0.9 \\
\hline Others & 10 & 8.8 & 4 & 3.5 & 9 & 8 & 4 & 3.5 \\
\hline
\end{tabular}

LMWH: Low molecular weight heparin. 
TABLE VI

Factors effective on changing venous thromboembolism prophylaxis preferences

\begin{tabular}{lccc}
\hline Factors & $\mathrm{n}$ & $\%$ & $95 \% \mathrm{Cl}$ \\
\hline Congress presentations & 52 & 46 & $37-55$ \\
Problems encountered during drug use & 46 & 40 & $32-49$ \\
Practices of colleagues & 44 & 39 & $30-48$ \\
Scientific articles & 43 & 38 & $29-47$ \\
AAOS guideline & 41 & 36 & $28-45$ \\
ACCP guideline & 21 & 19 & $12-26$ \\
NICE guideline & 12 & 10 & $6-17$ \\
Bleeding complication & 15 & 13 & $8-20$ \\
\hline
\end{tabular}

Cl: Confidence interval; AAOS: American Academy of Orthopedic Surgeons; ACCP: American College of Chest Physicians; NICE: National Institute for Health and Care Excellence.

TABLE VII

Relationship between academic positions and factors that affect venous thromboembolism prophylaxis changes

\begin{tabular}{|c|c|c|c|c|c|c|c|c|c|c|c|c|}
\hline & \multicolumn{2}{|c|}{$\begin{array}{c}\text { AAOS } \\
\text { Guideline }\end{array}$} & \multicolumn{2}{|c|}{$\begin{array}{c}\text { ACCP } \\
\text { Guideline }\end{array}$} & \multicolumn{2}{|c|}{$\begin{array}{c}\text { Congress } \\
\text { presentations }\end{array}$} & \multicolumn{2}{|c|}{$\begin{array}{l}\text { Scientific } \\
\text { articles }\end{array}$} & \multicolumn{2}{|c|}{$\begin{array}{c}\text { Problems } \\
\text { encountered } \\
\text { during in drug use }\end{array}$} & \multicolumn{2}{|c|}{$\begin{array}{c}\text { Experiences of } \\
\text { colleagues }\end{array}$} \\
\hline & $\mathrm{n}$ & $\%$ & $\mathrm{n}$ & $\%$ & $\mathrm{n}$ & $\%$ & $\mathrm{n}$ & $\%$ & $\mathrm{n}$ & $\%$ & $\mathrm{n}$ & $\%$ \\
\hline Operator & 16 & 23.7 & 7 & 10.4 & 29 & 43.3 & 16 & 23.9 & 31 & 46.3 & 29 & 43.3 \\
\hline Assistant professor & 5 & 35.7 & 1 & 7.1 & 7 & 50.0 & 6 & 42.9 & 5 & 35.7 & 7 & 50.0 \\
\hline Associate professor & 13 & 68.4 & 8 & 42.1 & 12 & 63.2 & 14 & 73.7 & 7 & 36.8 & 7 & 36.8 \\
\hline Professor & 7 & 58.3 & 5 & 41.7 & 4 & 33.3 & 6 & 50.0 & 2 & 16.7 & 1 & 8.3 \\
\hline
\end{tabular}

AAOS: American Academy of Orthopedic Surgeons; ACCP: American College of Chest Physicians.

Note: Surgeons were offered to choose more than one cause.

due to problems encountered by patients when using drugs as reference.

Of the surgeons participating in the survey, $118(32.7 \%)$ were using a risk classification system to choose a VTE prophylaxis method. Risk classification system was most used by surgeons working at university hospitals $(40.2 \%)$ and least used by surgeons working at district state hospitals $(16.3 \%)(\mathrm{p}<0.05)$. Regarding academic positions, professors used risk classification the most $(62.2 \%)$ while operators used the least $(23 \%)(\mathrm{p}<0.05)$ (Table III).

\section{DISCUSSION}

In this study, we found that the usage of aspirin for VTE prophylaxis increased from $10.6 \%$ to $43.4 \%$ and from $9.7 \%$ to $37.2 \%$ after TKA and THA, respectively. We also found that the usage of oral anticoagulant increased from $11.5 \%$ to $41.6 \%$ and from $10.6 \%$ to $39.8 \%$ after TKA and THA, respectively.

Venous thromboembolism is a serious complication after knee and hip arthroplasty. ${ }^{[7]}$ Hence, VTE prophylaxis is recommended after TKA and THA. However, potent anticoagulants used in VTE prophylaxis have been reported to cause bleeding, ${ }^{[1]]}$ wound problems, ${ }^{[12]}$ hematoma, ${ }^{[12]}$ reoperation, ${ }^{[13]}$ and infection. ${ }^{[12]}$ Moreover, potent anticoagulants did not reduce the incidence of symptomatic VTE and mortality. ${ }^{[14]}$ The multimodal prophylaxis which includes early onset of mobilization, use of intermittent pressure devises for mechanical prophylaxis, and use of aspirin have gained popularity by providing effective VTE prophylaxis and reducing risk of bleeding ${ }^{[1,15-17]}$ Numerous studies using this method have been published in last two decades. The organizations that prepare guidelines for VTE prophylaxis started to take these studies into consideration. AAOS issued a guideline in 2007 which recommended the use of aspirin $325 \mathrm{mg}$ twice daily for six weeks for patients at standard risk of pulmonary embolism (PE) and major bleeding, those with a standard risk of PE and elevated risk of major bleeding, and those with an elevated risk of PE and major bleeding groups separately. ${ }^{[18]}$ In 2011, AAOS suggested that any of the anticoagulants may be preferred considering bleeding and VTE prophylaxis in balance. ${ }^{[19]}$ The seventh and eighth editions of the ACCP guidelines, published in 2004 and 2008, 
respectively, recommended against the use of aspirin for VTE prophylaxis in patients undergoing arthroplasty. ${ }^{[20,21]}$ However, the ninth ACCP guideline published in 2012 recommended mechanical prophylaxis, aspirin and oral anticoagulants for VTE prophylaxis. ${ }^{[7]}$ Although few studies have reported discrepancies between the ACCP guideline and clinical practice after major orthopedic surgery, ${ }^{[22,23]}$ the compliance of orthopedic surgeons with these changes in clinical practice guidelines needs to be adequately explored. In a meta-analysis published in 2016, the compliance with ACCP recommendations after major orthopedic surgery increased over time; however, post-discharge compliance was reported to be inadequate. ${ }^{[2]}$ A survey conducted with 222 orthopedic surgeons in Korea in 2011-2012 reported that the rate of routine VTE prophylaxis was $60.4 \%$, the rate of prophylaxis according to the patient's health status was $19.4 \%$, and the rate of no prophylaxis was reported as $20.2 \%$. In the same study, compression bandages were the most commonly used method $(72.9 \%)$, and direct factor Xa inhibitors were pharmacologically the most preferred drugs (46.9\%). ${ }^{[25]}$ Another survey conducted in Australia in 2009 reported that 98\% of orthopedic surgeons prefer pharmacological prophylaxis and largely use LMWH (TKA 84\%, THA 79\%). ${ }^{[6]}$ Moreover, a survey conducted in 2008 showed that $85 \%$ and $89 \%$ of orthopedic surgeons read ACCP and AAOS guidelines in the USA, respectively. However, the majority of participants agreed with the AAOS guideline (88\%) instead of the ACCP guideline (30\%). ${ }^{[27]}$ Again, in this study, the aspirin preference rate for VTE prophylaxis after arthroplasty in the USA was lower than $1 \%$. On the other hand, a survey conducted at the American Association of Hip and Knee Surgeons meeting in 2016 reported that aspirin was the most preferred agent for VTE prophylaxis in patients undergoing arthroplasty $(80 \%) .{ }^{[28]}$ These factors may explain why the use of aspirin has increased in recent years: adequate VTE prophylaxis in most patients, ${ }^{[29]}$ less bleeding and no requirement for monitoring, ${ }^{[30]}$ being inexpensive and safe, ${ }^{[31,32]}$ causing less wound problems, ${ }^{[33]}$ reducing the risk of periprosthetic infection $^{[34]}$ and strong recommendations in favor of aspirin in recent clinical practice guidelines. ${ }^{[7,18]}$

Our survey demonstrated that the use of oral anticoagulants for VTE prophylaxis has also increased in the last three years. A recent randomized controlled trial revealed that aspirin has similar efficacy compared with apixaban (an oral anticoagulant) in patients undergoing THA and TKA. ${ }^{[35]}$ Bloch et al. ${ }^{[36]}$ compared dabigatran (an oral anticoagulant) and multimodal prophylaxis (LMWH during hospitalization and aspirin during discharge) and found that dabigatran causes significantly increased leakage from the wound $(p<0.001)$ and higher rates of VTE $(p=0.047)$. Similarly, rivaroxaban has been reported to cause more hidden blood loss and more wound problems compared with LMWH and aspirin. ${ }^{[33]}$ We believe that it may be more rational to use oral anticoagulants in cases with high risk of VTE to avoid complications such as bleeding and wound problems.

Our study demonstrated that LMWH is still the most preferred VTE prophylaxis method $(75.7 \%$ and 74\% following TKA and THA, respectively) in Turkey. Three years ago, these rates were $92.1 \%$ and $88.5 \%$ after TKA and THA, respectively. The reasons for decreased LMWH use may be attributed to higher cost, subcutaneous use, bleeding complications and recommendations of recent guidelines in favor of other modalities such as aspirin, oral anticoagulants, and mechanical prophylaxis.

This study showed that congress presentations $(46 \%)$ were most effective factor in changing preferences for VTE prophylaxis. Therefore, it may be useful to present the current changes in VTE prophylaxis guidelines at congresses to increase awareness among orthopedic surgeons.

Risk assessment methods have been used to individualize VTE prophylaxis in patients undergoing arthroplasty. Nam et al. ${ }^{[37]}$ have used a risk assessment method and reduced the use of more potent anticoagulants by $70 \%$, while keeping symptomatic VTE risk low. A recent study by Parvizi et $a .^{[5]}$ used the United States Inpatient Sample data and identified 1,721,806 patients undergoing arthroplasty, among whom 15,775 (0.9\%) developed VTE postoperatively. According to this study, hypercoagulability, metastatic cancer, stroke, sepsis and chronic obstructive pulmonary disease had the highest risk scores. Patients with any of these conditions were found to have a VTE risk greater than 3\% postoperatively. Using this model, the authors have developed an iPhone operating system (Apple Inc., Cupertino, California) application (VTEstimator, MedApp LLC, Wilmington, Delaware) so that low and high-risk patients can be identified and the appropriate method for VTE prophylaxis may be selected.

According to our study, $32.2 \%$ of surgeons use risk assessment methods in Turkey. Surgeons working at university hospitals (40.2\%) and professors (62.2\%) use risk assessment methods most commonly. Considering that the majority of surgeons do not use 
risk assessment methods in Turkey, presenting this issue in training programs and congresses may be useful to raise awareness.

Our study has several limitations. Firstly, we did not classify the participants according to their work region. However, in an era of Internet and webinars, knowledge is easily accessible in all geographic regions. Secondly, the rate of revision surgery among the majority of participants was low. Hence, the results may not adequately reflect the VTE preferences in revision arthroplasties.

In conclusion, one-third of orthopedic surgeons have changed their preferences for VTE prophylaxis over the past three years in Turkey. Congressional presentations, difficulties experienced by patients when using drugs, and AAOS guidelines were found to be the most influential on the changes. In parallel to clinical practice guidelines, changes were in favor of aspirin and oral anticoagulants. It may be helpful to emphasize the risk assessment and individualized VTE prophylaxis concepts and present such changes at training programs and congresses. We suggest that Turkish Orthopedic Association may perform a survey regarding VTE prophylaxis among all orthopedic surgeons in Turkey. Also, the VTE study group may be activated and may prepare a guideline for VTE prophylaxis in patients undergoing TJA.

\section{Acknowledgments}

The authors did not receive any grants or outside funding in support of their research or preparation of this manuscript. They did not receive payments or other benefits or a commitment or agreement to provide such benefits from any commercial entity.

\section{Declaration of conflicting interests}

The authors declared no conflicts of interest with respect to the authorship and/or publication of this article.

\section{Funding}

The authors received no financial support for the research and/or authorship of this article.

\section{REFERENCES}

1. Ethgen $\mathrm{O}$, Bruyère $\mathrm{O}$, Richy $\mathrm{F}$, Dardennes $\mathrm{C}$, Reginster JY. Health-related quality of life in total hip and total knee arthroplasty. A qualitative and systematic review of the literature. J Bone Joint Surg Am 2004;86:963-74.

2. Altıntaş F, Uluçay C, Uğutmen E, Güven M, Unay K. Long-term use of fondaparinux in major orthopedic surgery. [Article in Turkish] Eklem Hastalik Cerrahisi 2012;23:168-72.

3. Spyropoulos AC, Lin J. Direct medical costs of venous thromboembolism and subsequent hospital readmission rates: an administrative claims analysis from 30 managed care organizations. J Manag Care Pharm 2007;13:475-86.

4. Elias P, Khanna R, Dudley A, Davies J, Jacolbia R, McArthur $\mathrm{K}$, et al. Automating Venous Thromboembolism Risk
Calculation Using Electronic Health Record Data upon Hospital Admission: The Automated Padua Prediction Score. J Hosp Med 2017;12:231-7.

5. Parvizi J, Huang R, Rezapoor M, Bagheri B, Maltenfort MG. Individualized risk model for venous thromboembolism after total joint arthroplasty. J Arthroplasty 2016;31:180-6.

6. Caprini JA, Arcelus JI, Hasty JH, Tamhane AC, Fabrega F. Clinical assessment of venous thromboembolic risk in surgical patients. Semin Thromb Hemost 1991;17:304-12.

7. Falck-Ytter Y, Francis CW, Johanson NA, Curley C, Dahl $\mathrm{OE}$, Schulman S, et al. Prevention of VTE in orthopedic surgery patients: Antithrombotic therapy and prevention of thrombosis, 9th ed: American College of Chest Physicians Evidence-Based Clinical Practice Guidelines. Chest 2012;141(2 Suppl):e278S-e325S.

8. Johanson NA, Lachiewicz PF, Lieberman JR, Lotke PA, Parvizi J, Pellegrini V, et al. American academy of orthopaedic surgeons clinical practice guideline on. Prevention of symptomatic pulmonary embolism in patients undergoing total hip or knee arthroplasty. J Bone Joint Surg [Am] 2009;91:1756-7.

9. Pellegrini VD Jr, Ferguson PC, Cruess R, Cruess S, Briggs TW. Sufficient competence to enter the unsupervised practice of orthopaedics: what is it, when does it occur, and do we know it when we see it? AOA Critical Issues. J Bone Joint Surg [Am] 2015;97:1459-64.

10. Azboy İ, Yalvaç ES, Azboy N, Şahin İ, Zehir S. Preferences of surgeons in total knee and hip arthroplasty, and operating room facilities in Turkey: a survey. [Article in Turkish] Eklem Hastalik Cerrahisi 2016;27:34-40.

11. Levine MN, Raskob G, Beyth RJ, Kearon C, Schulman S. Hemorrhagic complications of anticoagulant treatment: the Seventh ACCP Conference on Antithrombotic and Thrombolytic Therapy. Chest 2004;126:287-310.

12. Agaba P, Kildow BJ, Dhotar H, Seyler TM, Bolognesi M. Comparison of postoperative complications after total hip arthroplasty among patients receiving aspirin, enoxaparin, warfarin, and factor Xa inhibitors. J Orthop 2017;14:537-43.

13. Galat DD, McGovern SC, Larson DR, Harrington JR, Hanssen AD, Clarke HD. Surgical treatment of early wound complications following primary total knee arthroplasty. J Bone Joint Surg [Am] 2009;91:48-54.

14. Sharrock NE, Gonzalez Della Valle A, Go G, Lyman S, Salvati EA. Potent anticoagulants are associated with a higher allcause mortality rate after hip and knee arthroplasty. Clin Orthop Relat Res 2008;466:714-21.

15. Dorr LD, Gendelman V, Maheshwari AV, Boutary M, Wan Z, Long WT. Multimodal thromboprophylaxis for total hip and knee arthroplasty based on risk assessment. J Bone Joint Surg [Am] 2007;89:2648-57.

16. Salvati EA, Sharrock NE, Westrich G, Potter HG, Valle AG, Sculco TP. The 2007 ABJS Nicolas Andry Award: three decades of clinical, basic, and applied research on thromboembolic disease after THA: rationale and clinical results of a multimodal prophylaxis protocol. Clin Orthop Relat Res 2007;459:246-54.

17. Jiang Y, Du H, Liu J, Zhou Y. Aspirin combined with mechanical measures to prevent venous thromboembolism after total knee arthroplasty: a randomized controlled trial. Chin Med J (Engl) 2014;127:2201-5.

18. Parvizi J, Azzam K, Rothman RH. Deep venous thrombosis prophylaxis for total joint arthroplasty: 
American Academy of Orthopaedic Surgeons guidelines. J Arthroplasty 2008;23:2-5.

19. Cionac Florescu S, Anastase DM, Munteanu AM, Stoica IC, Antonescu D. Venous thromboembolism following major orthopedic surgery. Maedica (Buchar) 2013;8:189-94.

20. Geerts WH, Pineo GF, Heit JA, Bergqvist D, Lassen MR, Colwell CW, et al. Prevention of venous thromboembolism: the Seventh ACCP Conference on Antithrombotic and Thrombolytic Therapy. Chest 2004;126:338-400.

21. Geerts WH, Bergqvist D, Pineo GF, Heit JA, Samama CM, Lassen MR, et al. Prevention of venous thromboembolism: American College of Chest Physicians EvidenceBased Clinical Practice Guidelines (8th Edition). Chest 2008;133:381-453.

22. Selby R, Borah BJ, McDonald HP, Henk HJ, Crowther M, Wells PS. Impact of thromboprophylaxis guidelines on clinical outcomes following total hip and total knee replacement. Thromb Res 2012;130:166-72.

23. Arcelus JI, Felicissimo P. Venous thromboprophylaxis duration and adherence to international guidelines in patients undergoing major orthopaedic surgery: results of the international, longitudinal, observational DEIMOS registry. Thromb Res 2013;131:240-6.

24. Farfan M, Bautista M, Bonilla G, Rojas J, Llinás A, Navas J. Worldwide adherence to ACCP guidelines for thromboprophylaxis after major orthopedic surgery: A systematic review of the literature and meta-analysis. Thromb Res 2016;141:163-70.

25. Kim NK, Kim TK, Kim JM, Chun CH. Prophylaxis for venous thromboembolism following total knee arthroplasty: A survey of korean knee surgeons. Knee Surg Relat Res 2016;28:207-12.

26. Molnar RB, Jenkin DE, Millar MJ, Campbell D, Harris IA. The Australian arthroplasty thromboprophylaxis survey. J Arthroplasty 2012;27:173-9.

27. Anderson FA Jr, Huang W, Friedman RJ, Kwong LM, Lieberman JR, Pellegrini VD Jr. Prevention of venous thromboembolism after hip or knee arthroplasty: findings from a 2008 survey of US orthopedic surgeons. J Arthroplasty 2012;27:659-66.
28. Azboy I, Barrack R, Thomas AM, Haddad FS, Parvizi J. Aspirin and the prevention of venous thromboembolism following total joint arthroplasty: Commonly asked questions. Bone Joint J 2017;99:1420-30.

29. Parvizi J, Huang R, Restrepo C, Chen AF, Austin MS, Hozack WJ, et al. Low-dose aspirin is effective chemoprophylaxis against clinically important venous thromboembolism following total joint arthroplasty: A preliminary analysis. J Bone Joint Surg [Am] 2017;99:91-8.

30. Garfinkel JH, Gladnick BP, Roland N, Romness DW. Increased Incidence of Bleeding and Wound Complications With Factor-Xa Inhibitors After Total Joint Arthroplasty. J Arthroplasty 2018;33:533-6.

31. Mostafavi Tabatabaee R, Rasouli MR, Maltenfort MG, Parvizi J. Cost-effective prophylaxis against venous thromboembolism after total joint arthroplasty: warfarin versus aspirin. J Arthroplasty 2015;30:159-64.

32. Atik OS.. Aspirin is safe and cost-effective in preventing venous thromboembolism prophylaxis in arthroplasty. Eklem Hastalik Cerrahisi 2017;28:141.

33. Zou Y, Tian S, Wang Y, Sun K. Administering aspirin, rivaroxaban and low-molecular-weight heparin to prevent deep venous thrombosis after total knee arthroplasty. Blood Coagul Fibrinolysis 2014;25:660-4.

34. Huang R, Buckley PS, Scott B, Parvizi J, Purtill JJ. Administration of aspirin as a prophylaxis agent against venous thromboembolism results in lower incidence of periprosthetic joint infection. J Arthroplasty 2015;30:39-41.

35. Anderson DR, Dunbar M, Murnaghan J, Kahn SR, Gross $\mathrm{P}$, Forsythe $\mathrm{M}$, et al. Aspirin or Rivaroxaban for VTE prophylaxis after hip or knee arthroplasty. N Engl J Med 2018;378:699-707.

36. Bloch BV, Patel V, Best AJ. Thromboprophylaxis with dabigatran leads to an increased incidence of wound leakage and an increased length of stay after total joint replacement. Bone Joint J 2014;96:122-6.

37. Nam D, Nunley RM, Johnson SR, Keeney JA, Clohisy JC, Barrack RL. The effectiveness of a risk stratification protocol for thromboembolism prophylaxis after hip and knee arthroplasty. J Arthroplasty 2016;31:1299-306. 